\title{
METODE INTERPOLASI SPASIAL DALAM STUDI GEOGRAFI (Ulasan Singkat dan Contoh Aplikasinya)
}

\author{
Oleh: \\ Bambang Syaeful Hadi \\ Jurusan Pendidikan Geografi, FIS, UNY \\ bb_saifulhadi@lycos.com
}

\begin{abstract}
Abstrak
Dunia nyata sebagai objek kajian berbagai macam disiplin terlalu kompleks untuk dipahami, sehingga untuk keperluan pemahaman tersebut diperlukan pemodelan. Pemodelan yang diterapkan pada suatu wilayah tertentu dikenal dengan pemodelan spasial. Pemodelan spasial sering kali menghadapi kendala tidak lengkapnya data. Untuk mengatasi ketidaklengkapan data tersebut kemudian dilakukan interpolasi. Interpolasi spasial diperlukan dalam studi geografi, karena geografi memerlukan analisis spasial untuk memperoleh informasi suatu fenomena di suatu wilayah. Interpolasi memiliki banyak ragam metode, yang asing-masing memiliki karakteristik, dengan segala kelebihan dan kekurangannya untuk diterapkan pada berbagai medan yang kondisinya variatif. Metode interpolasi yang biasa digunakan dalam berbagai kajian secara garis besar diklasifikasikan menjadi 3, yakni: (1) metode interpolasi global dan lokal, (2) metode interpolasi eksak dan nun-eksak, dan (3) metode interpolasi determenistik dan stochastik. Masing-masing metode tersebut juga memiliki ragam yang lebih spesifik untuk diterapkan pada berbagai jenis medan. Dalam paper singkat ini dikemukakan berbagai metode tersebut disertai dengan penjelasan singkat dan contohnya.
\end{abstract}

Kata kunci: interpolasi spasial, ragam, aplikasi

\section{INTERPOLATION SPATIAL METHOD IN THE STUDY OF GEOGRAPHY (A brief review and examples of application)}

\begin{abstract}
$\underline{\text { Abstract }}$
The real world as the object of study for many different disciplines is too complex to understand. Therefore, it requires a modeling to understand. The modeling applied to a specific region known as spatial modeling. This modeling often gets problem of insufficient data. To overcome this problem, interpolation is performed. Spatial interpolation is needed in the study of geography because geography requires spatial analysis to obtain information of a phenomenon in a region. There are many types of interpolation methods in which each has its own characteristics, with all strengths and weaknesses to be applied in various fields and conditions. Interpolation methods which are often used in many studies can be classified into three, namely: (1) global and local interpolation method, (2) exact and non-exact interpolation method, and (3) determenistik and stochastik interpolation method. Moreover, each of these methods has more specific types to be applied to a variety of fields. This short paper presents various methods of interpolation and its examples.
\end{abstract}

Keywords: spatial interpolation, types, the application 


\section{Pendahuluan}

Untuk keperluan penyusunan model suatu fenomena di satu wilayah diperlukan data beberapa komponen data pendukung. Pada kenyataannya, sering kali seorang peneliti dihadapkan pada ketidaklengkapan data yang diperlukan. Di samping itu kondisi lingkungan setempat tidak memungkinkan untuk diterapkannya satu formula dengan hasil yang akurat. Untuk menyiasatinya, maka dilakukan interpolasi. Permaslahan lain yang sering kali menghambat satu survei adalah cakupan wilayah yang cukup luas dengan berbagai kondisi fisiografis, keterbatasan waktu dan dana, sehingga untuk keperluan efsisensi dan efektivitas, maka kajian dilakukan dengan menggunakan sampel.

Pertimbangan kondisi lingkungan, fisiografis, keterbatasan data dari berbagai titik di permukaan bumi ini dapat menghambat penyusunan model. Selanjutnya untuk menyusun suatu model yang baik disiasati dengan melakukan intepolasi. Interpolasi merupakan suatu metode atau fungsi matematika untuk menduga nilai pada lokasi-lokasi yang datanya tidak tersedia. Menurut Burrough and McDonell (1998), interpolasi adalah proses memprediksi nilai pada suatu titik yang bukan merupakan titik sampel, berdasarkan pada nilai-nilai dari titik-titik di sekitarnya yang berkedudukan sebagai sampel. Penentuan nilai baru didasarkan pada data yang ada pada titik-titik sampel pengamatan (lihat gambar 2). Tanpa adanya langkah interpolasi ini, maka analisis spasial tidak dapat dilakukan secara akurat.

Dalam konteks pemetaan, interpolasi merupakan proses estimasi nilai pada wilayah-wilayah yang tidak disampel atau diukur untuk keperluan penyusunan peta atau sebaran nilai pada seluruh wilayah yang dipetakan. Interpolasi spasial mempunyai dua asumsi yakni atribut data bersifat kontinu di dalam ruang (spcae) dan atribut tersebut saling berhubungan (dependence) secara spasial (Anderson, 2001). Kedua asumsi tersebut berimplikasi pada logika bahwa pendugaan atribut data dapat dilakukan berdasarkan data dari lokasi-lokasi di sekitarnya dan nilai pada titik-titik yang berdekatan akan lebih mirip daripada nilai dari titik-titik yang berjauhan (Prasasti, Wijayanto, Christanto, 2005). Hal ini sesuai pula dengan hukum Tobler pertama. Untuk melakukan interpolasi spasial diperlukan data dari titik-titik kontrol (sampel), sehingga nilai dari titik yang tidak diketahui nilainya dapat destinasi. Posisi titik-titik kontrol untuk interpolasi spasial dan nilai data dapat diilustrasikan oleh Gambar 1 dan 2.

\section{Metode Interpolasi}

Ada beberapa metode yang dapat digunakan untuk melakukan interpolasi spasial. Menurut Demers (2000), interpolasi spasial dapat diklasifikasikan menjadi tiga, yakni global and local interpolation, exact interpolation and inexact interpolation, deterministic and stochastic interpolation.

1. Interpolasi Global and lokal

a. Interpolasi global

Interpolasi global menggunakan semua titik kontrol yang tersedia. Cukup memadai untuk diterapkan pada medan yang tidak menunjukkan variasi yang kompleks. Interpolasi ini memiliki asumsi bahwa autokorelasi spasial baik pada skala regional. Estimasi yang diperoleh lebih bersifat umum. Contoh penggunaan 
interpolasi global dengan trend surface orde pertama (polynomial): $Z x y=b_{0}+b_{1} x+b_{2} y$
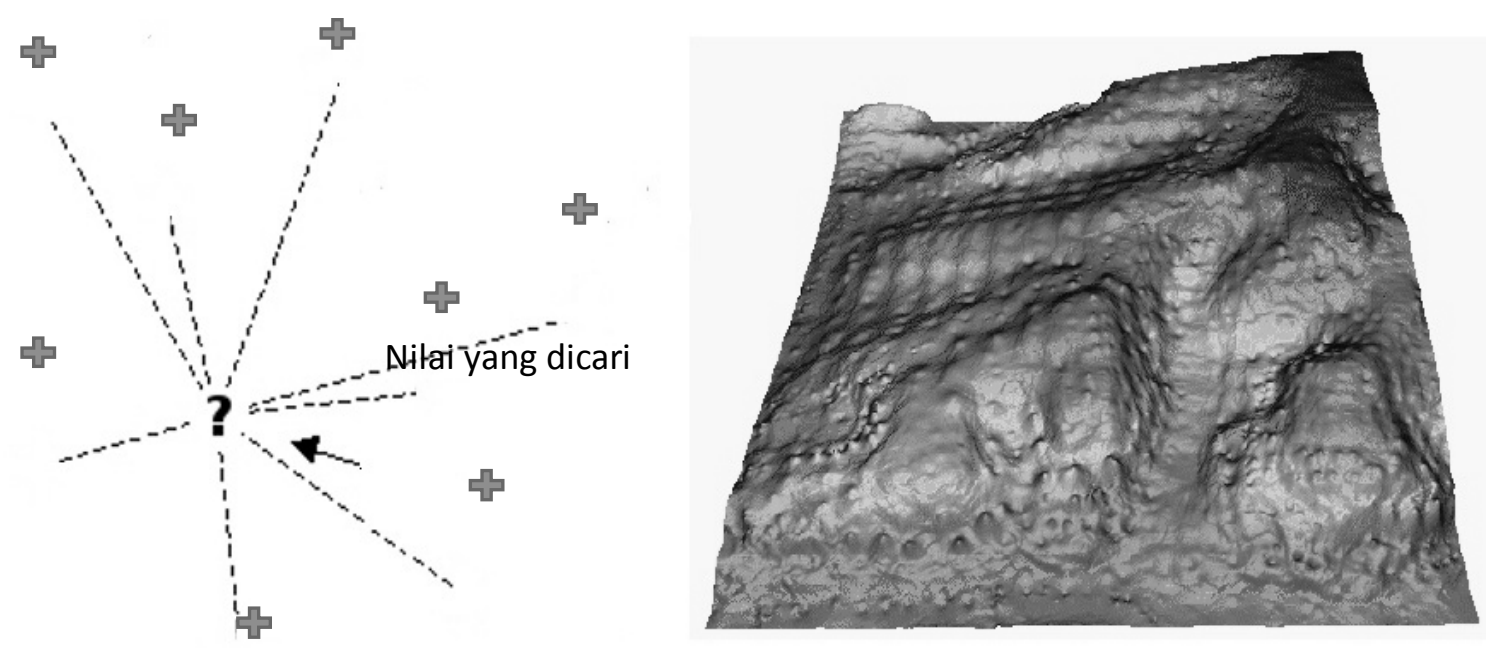

Gambar 1. Ilustrasi sederhana posisi titik-titik yang akan diinterpolasi spasial

\begin{tabular}{|l|l|l|l|l|l|}
\hline 1 & & 3 & 4 & & 6 \\
\hline & 2 & & & & \\
\hline & 2 & & 4 & 5 & \\
\hline & & & & & \\
\hline 1 & & 3 & & & 6 \\
\hline & & & & & \\
\hline
\end{tabular}$\quad \sqrt{1}$\begin{tabular}{|l|l|l|l|l|l|}
\hline 1 & 2 & 3 & 4 & 5 & 6 \\
\hline 1 & 2 & 3 & 4 & 5 & 6 \\
\hline 1 & 2 & 3 & 4 & 5 & 6 \\
\hline 1 & 2 & 3 & 4 & 5 & 6 \\
\hline 1 & 2 & 3 & 4 & 5 & 6 \\
\hline 1 & 2 & 3 & 4 & 5 & 6 \\
\hline
\end{tabular}

Gambar 2. Interpolasi sebagai prosedur untuk memprediksi nilai-nilai yang tidak diketahui berdasarkan nilai-nilai yang diketahui dari titik-titik yang diketahui

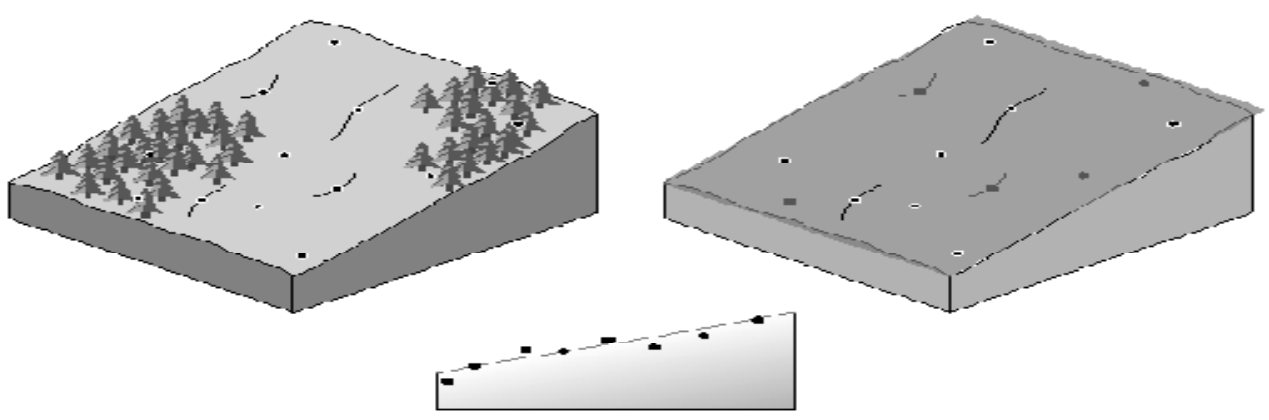

Gambar 3. Permukaan yang sesuai untuk interpolasi global orde satu 


\begin{tabular}{|l|l|l|c|}
\hline \multicolumn{1}{|c|}{ Titik } & \multicolumn{1}{c|}{$x$} & \multicolumn{1}{c|}{$y$} & nilai \\
\hline 1 & 79 & 76 & 21,82 \\
\hline 2 & 69 & 64 & 11,91 \\
\hline 3 & 85 & 52 & 11,38 \\
\hline 4 & 96 & 73 & 15,60 \\
\hline 5 & 98 & 53 & 11,56 \\
\hline 0 & 79 & 77 & $?$ \\
\hline
\end{tabular}

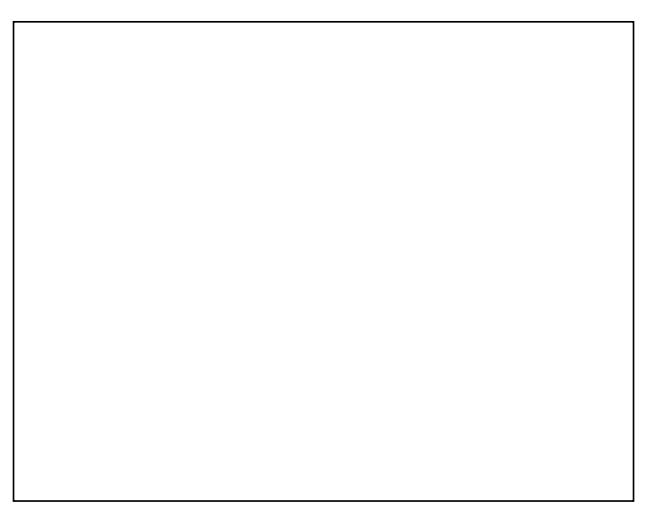

Gambar 4. Contoh data untuk tindakan interpolasi global

Berdasarkan persamaan di atas selanjutnya dapat diturunkan persamaan berikutnya:

1. Menyusun persamaan

$$
\begin{aligned}
& \sum z=b_{0} n+b_{1} \sum x+b_{2} \sum y \\
& \sum x z=b_{0} n+b_{1} \sum x+b_{2} \sum y \\
& \sum x z=b_{0} n+b_{1} \sum x+b_{2} \sum y
\end{aligned}
$$

2. Menuliskan kembali persamaan di atas dalam bentuk matriks

$$
\left[\begin{array}{ccc}
n & \Sigma x & \Sigma y \\
\Sigma x & \Sigma x^{2} & \Sigma x y \\
\Sigma y & \Sigma x y & \Sigma y^{2}
\end{array}\right] \times\left[\begin{array}{l}
b_{0} \\
b_{1} \\
b_{2}
\end{array}\right]=\left[\begin{array}{c}
\Sigma z \\
\Sigma x z \\
\Sigma y z
\end{array}\right]
$$

3. Menghitung data dari titik-titik yang telah ada

\begin{tabular}{|r|r|r|r|r|r|r|r|}
\hline \multicolumn{1}{|c|}{$\mathrm{X}$} & \multicolumn{1}{|c|}{$\mathrm{Y}$} & \multicolumn{1}{c|}{$\mathrm{Z}$} & $\mathrm{X}^{2}$ & \multicolumn{1}{c|}{$\mathrm{Y}^{2}$} & \multicolumn{1}{c|}{$\mathrm{XY}$} & \multicolumn{1}{c|}{$\mathrm{XZ}$} & \multicolumn{1}{c|}{$\mathrm{YZ}$} \\
\hline 79 & 86 & 21,82 & 6241 & 7396 & 6794 & 1723,78 & 1876,52 \\
\hline 69 & 74 & 11,91 & 4761 & 5476 & 5106 & 821,79 & 881,34 \\
\hline 85 & 62 & 11,38 & 7225 & 3844 & 5270 & 967,3 & 705,56 \\
\hline 96 & 83 & 15,61 & 9216 & 6889 & 7968 & 1498,56 & 1295,63 \\
\hline 98 & 63 & 11,56 & 9604 & 3969 & 6174 & 1132,88 & 728,28 \\
\hline & & & & & & & \\
\hline 427 & 368 & 72,28 & 37047 & 27574 & 31312 & 6144,32 & 5487,33 \\
\hline
\end{tabular}

$$
\begin{aligned}
& \Sigma X=427 \\
& \Sigma Y=368 \\
& \Sigma Z=72,28 \\
& \Sigma X^{2}=37047 \\
& \Sigma Y^{2}=27574 \\
& \Sigma X Y=31312 \\
& \Sigma Y Z=6144,32 \\
& \Sigma X Z=5487,33
\end{aligned}
$$


4. Masukkan nilai-nilai dari lima titik dalam matriks

$\left[\begin{array}{ccc}5 & 427 & 368 \\ 427 & 37047 & 31312 \\ 368 & 31312 & 27574\end{array}\right] \times\left[\begin{array}{l}b_{0} \\ b_{1} \\ b_{2}\end{array}\right]=\left[\begin{array}{c}72,28 \\ 5487,33 \\ 6144,32\end{array}\right]$

5. Hitunglah koefisien $b$

$\left[\begin{array}{ccc}30,32085 & -0,18541 & -0,19411 \\ -0,18541 & 0,001805 & 0,000425 \\ -0,19411 & 0,000425 & 0,002144\end{array}\right] \times\left[\begin{array}{c}72,28 \\ 5487,33 \\ 6144,32\end{array}\right]=\left[\begin{array}{c}-12,7978 \\ 0,019956 \\ 0,347140\end{array}\right]$

6. Menggunakan koefisien $b$ untuk menghitung nilai " $z$ " untuk beberapa titik $(X, Y)$, dalam hal ini adalah $(79,77)$, dengan menggunakan persamaan

$$
\begin{aligned}
Z_{x y} & =b_{0}+b_{1 x}+b_{2 y} \\
Z_{0} & =-12,7978+0,01996(79)+0,347(77) \\
& =15,50
\end{aligned}
$$

Untuk melakukan interpolasi pada permukaan alami yang kompleks maka perlu dilakukan dengan menggunakan trend surface orde yang lebih tinggi (lihat gambar $\mathrm{x}$ )

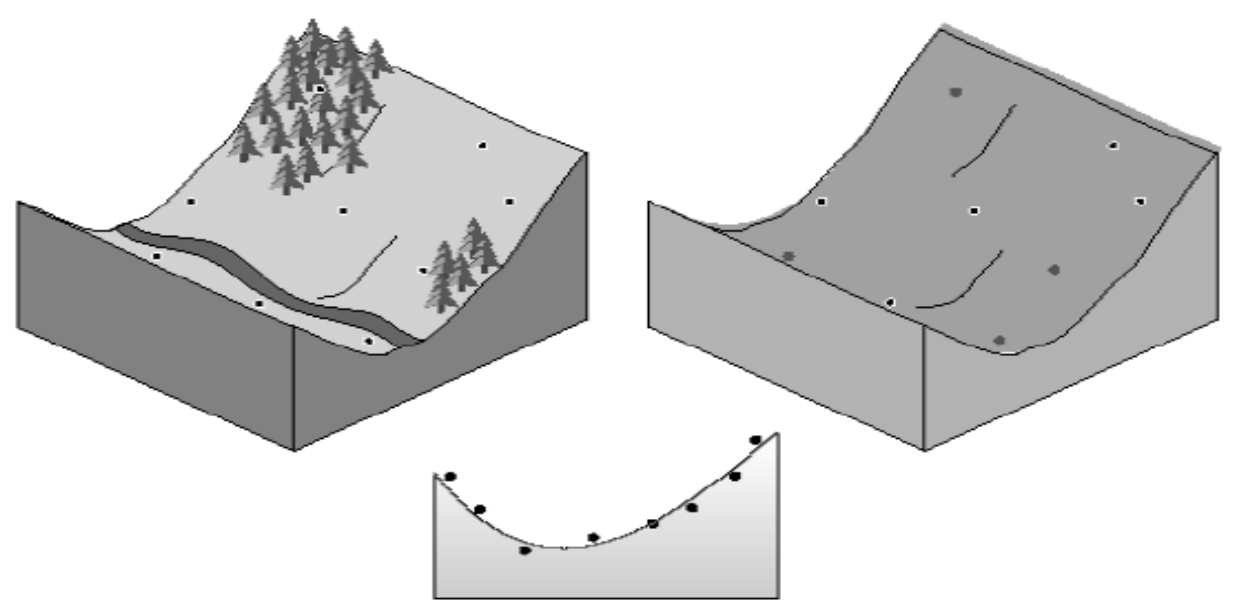

Gambar 5. Permukaan alami yang cukup kompleks

Perhitungan interpolasi dapat dilakukan dengan menggunakan persamaan berikut :

$$
Z x, y=b_{0}+b_{1} x+b_{2} y+b_{3} x^{2}+b_{4} x y+b_{5} y^{2}+b_{6} x^{3}+b_{7} x^{2} y+b_{8} x y^{2}+b_{9} y^{3}
$$

Interpolasi lokal hanya menggunakan sampel titik-titik kontrol. Metode ini sesuai untuk medan yang menunjukkan variasi yang kompleks. Asumsi dari metode ini adalah autokorelasi spasial baik pada skala lokal. Nilai-nilai hasil estimasi lebih bersifat lokal. Prosedur umum untuk mengidentifikasi titik-titik akan destinasi mencakup langkah-langkah (1). Sebuah wilayah pencarian (bertetanggan) didefinisikan sekitar titik; (2). Titik-titik sampel dalam area penelitian diidentifikasi; (3). Sebuah fungsi matematika yang dipilih untuk memodelkan variasi lokal antara titiktitik; (4). Nilai data untuk titik diperkirakan dari fungsi. 


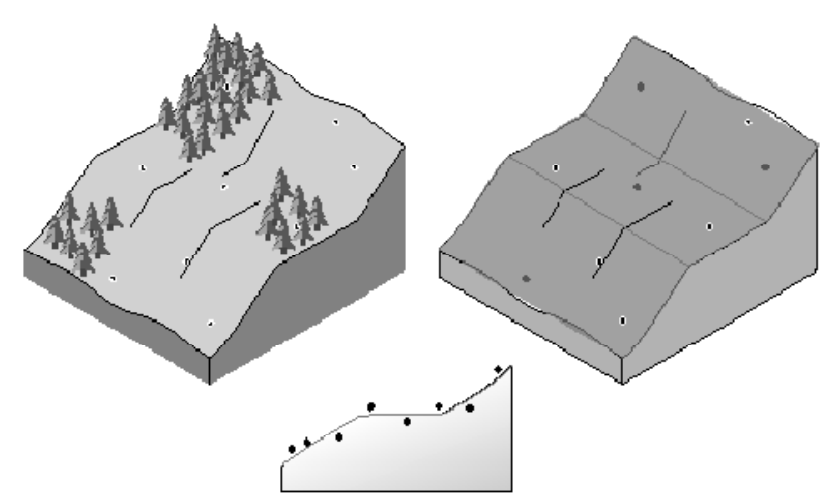

Gambar 6. Permukaan bumi yang mememerlukan interpolasi lokal

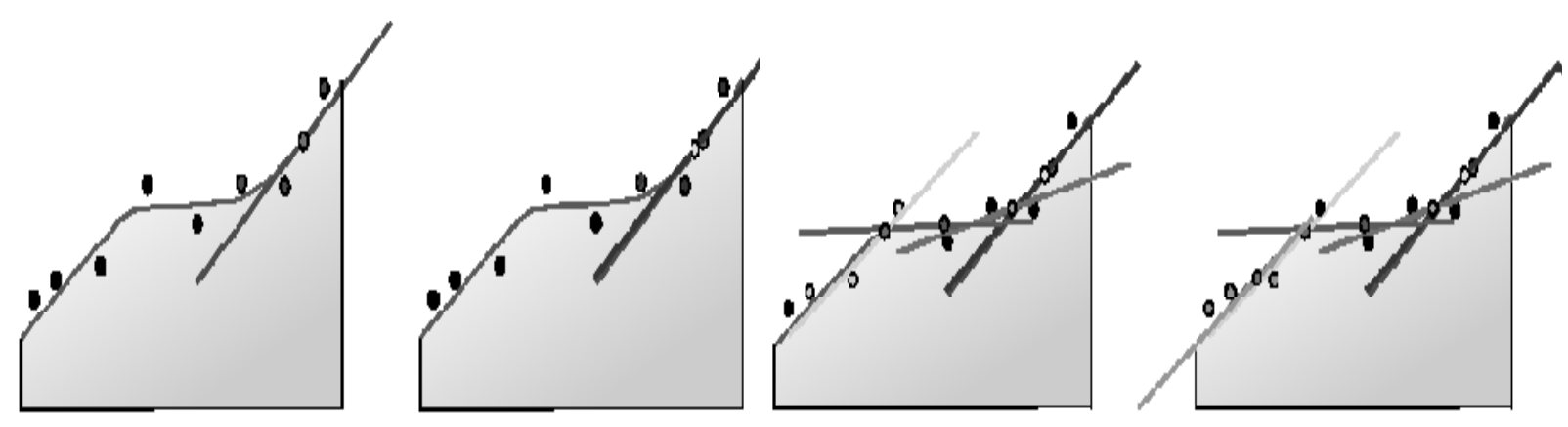

Gambar 7. Skema posisi titik kontrol untuk interpolasi lokal

Interpolasi lokal setidaknya dapat dilakukan melalui beberapa cara, antara lain dengan metode:

1. Tren (polynomial) lokal

Polinomial lokal merupakan lawan dari polinomial global, dimana polinomial lokal dapat diterapkan untuk merepresentasikan permukaan sebagaimana diilustrasikan gambar 6 .

2. Poligon Theissen

Poligon Theissen, yang disebut juga metode proximal merupakan suatu upaya memberikan bobot data titik-titik di suatu area. Sebagai contoh untuk interpolasi lokal untuk data presipitasi. Langkahnya adalah sejumlah segitiga digambar dengan cara menghubungkan titik-titik kontrol (misalnya, stasiun meteorologi) menggunakan teknik triangulasi Delaunay (juga digunakan untuk TIN). Garis ditarik tegak lurus terhadap sisi segitiga di titik tengah. Poligon didefinisikan oleh persimpangan (interaksi) dari garis-garis. Nilai-nilai untuk titik kontrol ditugaskan untuk merepresentasikan poligon

3. Estimasi kepadatan

Fungsi kepadatan sederhana menggambarkan jumlah poin/ukuran sel (misalnya, $10.000 \mathrm{~m} 2$ ) (ditampilkan dalam warna-warna tertentu, misal abu-abu), ukuran lingkaran berpusat di pusat ukuran sel. Metode lain yang termasuk metode estimasi kepadatan adalah Kernel Density Estimation. Fungsi densitas kernel adalah alternatif yang umum digunakan. 
4. Inverse Distance Weighted (IDW)

Metode IDW merupakan metode interpolasi konvesional yang memperhitungkan jarak sebagai bobot. Jarak yang dimaksud disini adalah jarak (datar) dari titik data (sampel) terhadap blok yang akan diestimasi. Jadi semakin dekat jarak antara titik sampel dan blok yang akan diestimasi maka semakin besar bobotnya, begitu juga sebaliknya.

$Z_{0}=$ Perkiraan nilai pada titik 0

$$
Z_{0}=\frac{\sum_{i=1}^{S} Z_{i} \frac{1}{d_{i}^{k}}}{\sum_{i=1}^{S} \frac{1}{d_{i}^{k}}}
$$

$Z i=$ Apakah nilai $z$ pada titik kontrol $i$

$d_{1}=$ Jarak antara titik I dan titik 0

$k=$ Semakin besar $k$, semakin besar pengaruh poin tetangga.

$S=$ jumlah titik $S$ yang digunakan

Contoh: jika terdapat titik A, B, C, D, dengan nilai asing-masing 20,82, 10,91, $10,38,14,60,10,56$, maka nilai Z0 dapat dicari sebagai berikut:

\begin{tabular}{|l|l|l|l|l|}
\hline \multicolumn{1}{|c|}{$Z_{1}$} & \multicolumn{1}{|c|}{$d_{1}$} & \multicolumn{1}{c|}{$d_{1}{ }^{2}$} & $1 /\left(d_{1}{ }^{2}\right)$ & \multicolumn{1}{c|}{$Z_{1} \times 1 /\left(d_{1}{ }^{2}\right)$} \\
\hline 20,82 & 18 & 324 & 0,0031 & 0,06426 \\
\hline 10,91 & 20,88 & 435,97 & 0,0023 & 0,02502 \\
\hline 10,38 & 32,31 & 1043,90 & 0,0010 & 0,00994 \\
\hline 14,60 & 36,05 & 1299,60 & 0,0008 & 0,01123 \\
\hline 10.56 & 47,20 & 2227,80 & 0,0004 & 0,00474 \\
\hline Jumlah & & & 0,0076 & 0,11520 \\
\hline
\end{tabular}

\begin{tabular}{|l|l|l|}
\hline \multicolumn{1}{|c|}{$\mathrm{Z}_{1}$} & \multicolumn{1}{|c|}{$\begin{array}{c}\text { Titik } \\
\text { antara }\end{array}$} & \multicolumn{1}{|c|}{$\begin{array}{c}\text { jarak } \\
\left(\mathrm{d}_{1}\right)\end{array}$} \\
\hline 20,82 & 0,1 & 18 \\
\hline 10,91 & 0,2 & 20,88 \\
\hline 10,38 & 0,3 & 32,31 \\
\hline 14,60 & 0,4 & 36,05 \\
\hline 10.56 & 0,5 & 47,20 \\
\hline
\end{tabular}

Jika diasumsikan $\mathrm{k}=2$, maka

$\Sigma Z_{1} \times 1 /\left(d_{1}^{2}\right)=(20,820)(18.000)^{2}+(10,910)(1 / 20,880)^{2}+(10,380)(1 / 32,310)^{2}+(14,600)(1 /$ $36.056)^{2}+(10,560)(1 / 32.310)^{2}=0,1152$

$\Sigma 1 /\left(d_{1}^{2}\right)=(1 / 18000) 2+(1 / 20.880) 2+(1 / 32.310) 2+(1 / 36.056) 2+(1 / 47,202) 2=0,0076$

$Z_{0}=0,1152 / 0,0076=15,158$

5. Radial Basis Function (RBF) Splines

Metode ini merupakan metode interpolasi eksak yang melibatkan sekelompok besar titik kontrol. Perbedaan antar titik kontrol pada setiap permukaan harus sesuai. Setiap RBF juga memiliki parameter yang mengontrol kesesuaian 
dihasilkan pada setiap permukaan. Atas dasar ketatnya persyaratan ini, sehingga perbedaan antara output dari metode ini adalah kecil. RBF banyak digunakan untuk peramalan data time series musiman, seperti curah hujan, debit sungai, produksi tanaman pertanian, dan lain-lain.

\section{Exact interpolation and inexact interpolation}

Interpolasi eksak merupakan cara memprediksi nilai pada titik kontrol yang sama dengan nilai yang diobservasi. Interpolasi menghasilkan permukaan yang lewat titik kontrol (lihat gambar 3a). Sedangkan inexact interpolation digunakan untuk memprediksi nilai untuk titik kontrol yang berbeda dari nilai yang diamati (lihat gambar 3b)
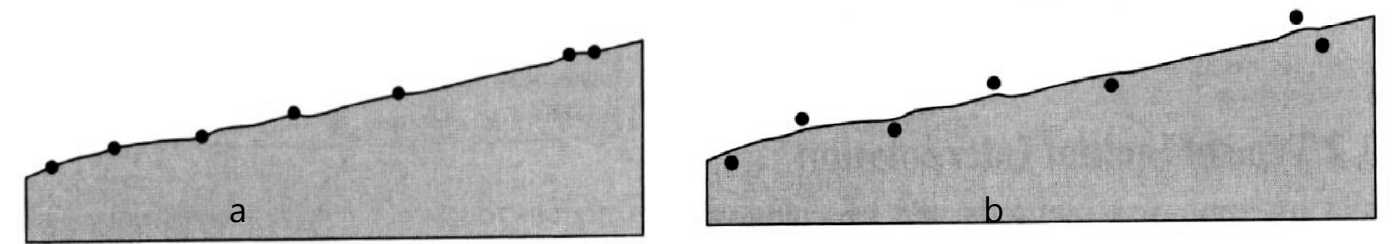

Gambar 3. Titik-titik kontrol untuk interpolasi exact (a) dan inexact (b)

3. Deterministic and stochastic interpolation.

Interpolasi deterministik tidak ada penilaian kesalahan dengan nilai prediksi. Contoh model determenistik sederhana adalah Inverse Distance Weighted (IDW). Asumsi dari metode IDW adalah nilai interpolasi akan lebih mirip pada data sampel yang berdekatan lokasinya daripada data yang lokasinya lebih jauh.

Contoh klasifikasi metode interpolasi spasial dapat dilihat pada tabel berikut:

\begin{tabular}{|l|l|l|l|}
\hline \multicolumn{2}{|c|}{ Global } & \multicolumn{2}{c|}{ Lokal } \\
\hline Determenistik & Stochastik & Determenistik & Stochastik \\
\hline Trend surface & Regression & Thiessen (exact) & Kriging (exact) \\
(inexact) & (inexact) & Density estimation (inexact) & \\
& & Inverse distance Weights & \\
& & (exact) & \\
& & Splines (exact) & \\
\hline
\end{tabular}

Sumber: Demers, 2006

Esri (2004) mempunyai klasifikasi metode interpolasi yang berbeda dengan klasifikasi di atas. Menurutnya teknik interpolasi deterministik dapat dibagi menjadi dua kelompok, global dan lokal. Teknik global melakukan hitungan untuk prediksi menggunakan seluruh dataset. Teknik lokal menghitung prediksi dari titik-titik yang diukur (sampel) dalam lingkungan, yang ukurannya wilayahnya lebih kecil-kecil secara spasial dalam wilayah penelitian yang lebih besar. Analis geostatistik menyediakan Polinomial global sebagai interpolator global dan Jarak Inverse Tertimbang, Polinomial Lokal, dan Basis Fungsi Radial sebagai interpolators lokal.

Sebuah interpolasi deterministik dapat menghasilkan model permukaan dengan cara mengetahui nilai data atau tidak. Sebuah teknik interpolasi yang memprediksi nilai yang identik dengan nilai yang diukur pada lokasi sampel dikenal sebagai interpolator eksakta. Interpolator ineksakta memprediksi nilai yang berbeda dari nilai yang terukur. 
Ineksakta ini dapat digunakan untuk menghindari puncak tajam atau lembah di permukaan output. Inverse Distance Weighted dan Fungsi Radial Basis adalah interpolators eksakta, sementara Polinomial global dan Polinomial lokal termasuk metode interpolasi ineksakta.

Diantara metode deterministik yang populer adalah Trend, Spline, Inverse Distance Weighted (IDW) dan Krigging. Setiap metode tersebut memiliki karakteristik yang berbeda-beda, sehingga jika diterapkan pada daerah yang sama akan diperoleh hasil interpolasi yang berbeda. Pada tulisan singkat ini, akan dibahas penggunaan metode IDW dan Kriging untuk kajian persebaran temperatur dan curah hujan. Metode interpolasi yang sederhana tetapi memiliki nilai akurasi yang cukup baik. Metode IDW dapat dikelompokkan ke dalam estimasi determenistik, yakni interpolasi dilakukan berdasarkan perhitungan matematika. Sementara metode Kriging dapat digolongkan ke dalam estimasi stochastik, di mana perhitungan secara statistik digunakan untuk menghasilkan interpolasi (Pramono, 2008).

Interpolasi stochastic menawaran penilaian kesalahan dengan nilai prediksi. Metode ini mengasumsikan kesalahan acak. Contoh model ini yang populer adalah metode Kriging. Metode Kriging merupakan estimasi stochastik yang mirip dengan IDW, menggunakan kombinasi linear dari weights untuk memperkirakan nilai di antara sampel data. Metode ini dikembangkan oleh D.L. Krige untuk memperkirakan nilai dari bahan tambang. Asumsi dari model ini adalah jarak dan orientasi antara sampel data menunjukkan korelasi spasial. Model ini memberikan ukuran error dan confidence. Model ini juga menggunakan semivariogram yang merepresentasikan perbedaan spasial dan nilai di antara semua pasangan sampel data. Semivarogram ini menunjukkan bobot (weights) yang digunakan dalam interpolasi. Semivarogram dihitung berdasarkan sampel semivarogram dengan jarak $h$, beda nilai $z_{1}$ dan jumlah sampel data $n$, berdasarkan persamaan berikut:

$$
\gamma(\mathrm{h})=\frac{1}{2 n} \sum_{i=1}^{n}\{Z(x i)-Z(x i+h)\}^{2}
$$

Pada jarak yang dekat (sumbu horisontal), semivariance bernilai kecil, tetapi pada jarak yang lebih besar, semi-variance bernilai tinggi yang menunjukkan bahwa variasi dari nilai $z$ tidak lagi berhubungan dengan jarak sampel point. 


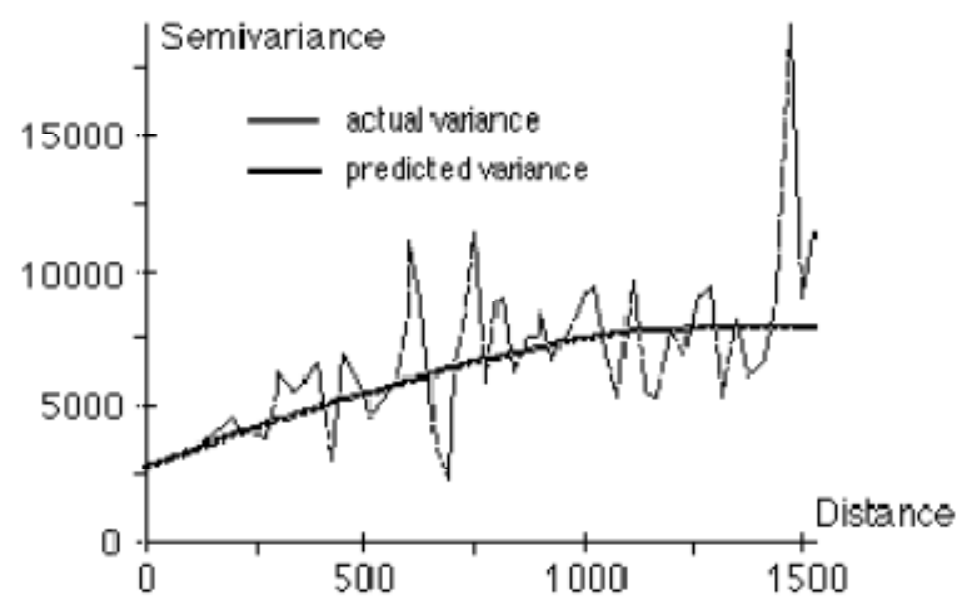

Gambar 4. Grafik semivariogram (Esri, 1999)

\section{Kesimpulan}

Fenomena geografis di permukaan bumi memiliki kondisi yang kompleks sehingga untuk memudahkan pemahaman terhadap fenomena tersebut memerlukan pemodelan. Diantara berbagai cara pemodelan, salah satu jenis pemodelan disebut pemodelan spasial. Dinyatakan demikian karena realitas fenomena yang hendak dimodelkan berupa data spasial. Untuk menyusun model spasial diperlukan data yang lengkap. Kenyataannya kelengkapan data sering tidak tersedia, sehingga harus dilakukan interpolasi. Interpolasi memiliki berbagai macam metode. Masing-masing metode memiliki kelemahan dan kelebihan, karena masing-masing disusun berdasarkan asumsi dan kondisi fenomena. Oleh karena itu pemanfaatan metode perlu mempertimbangkan karakteristik fenomena di lapangan.

\section{DAFTAR PUSTAKA}

DeMers, Michael N, 2000. Fundamentals of Geographic Information Systems. Second Edition. Jhon Wiley and Sons, New York.

ESRI, 2008. Deterministic methods for spatial interpolation. Terdapat di http://webhelp.esri.com/ArcGISdesktop/9.3/index.cfm?TopicName=Deterministi c_methods_for_spatial_interpolation

Pramono, Gatot.H, 2008. Akurasi Metode IDW dan Krigging untuk Interpolasi Sebaran Sedimen Tersuspensi. Forum Geografi, Vol. 22, No.1, h.97-110

Prasasti, Indah, Hari Wijayanti, dan Maulana Christanto, 2005. Analisis Penerapan Metode Krigging dan Invers Distance pada Interpolasi Data Dugaan Suhu, Air Mampu Curah (AMC) dan Indeks Stabilitas Atmosfir (ISA) dari Data NOAA-TOVS. Makalah PIT Mapin XIV, ITS Surabaya 


\title{
KARAKTERISTIK PERINDUSTRIAN GENTENG DI DESA SIDOLUHUR KECAMATAN GODEAN KABUPATEN SLEMAN
}

\author{
Oleh : \\ Sriadi Setywati, Hastuti, dan Nurhadi \\ Jurusan Pendidikan Geografi, Fakultas Ilmu Sosial, Universitas Negeri Yogyakarta \\ Sriadigeo@yahoo.com
}

\begin{abstract}
Abstrak
Tujuan penelitian ini adalah untuk mengetahui: (1) faktor - faktor yang menyebabkan pengusaha industri genteng tidak berproduksi lagi,(2) faktor yang mendorong dan menarik pada usaha industri genteng,(3). persebaran pengusaha industri genteng. 4). Pemasaran dan peta pemasaran genteng di Desa Sidoluhur Kecamatan Godean Kabupaten Sleman.Populasi penelitian ini adalah mantan pengusaha industri genteng dan pengusaha industri genteng. Populasi mantan pengusaha industri genteng berjumlah 14 kepala rumah tangga, karena jumlahnya kurang dari 100, maka semua digunakan sebagai responden. Populasi pengusaha industri genteng berjumlah 388 kepala rumah tangga, tersebar pada delapan dusun. Penelitian ini mengambil sampel 126 kepala rumah tangga pengusaha. Dengan area sampling diambil tiga dusun sampel daerah penelitian, yaitu Dusun Berjo Kulon 48 kepala rumah tangga, Berjo Kidul 33 kepala rumah tangga dan Serangan 45 kepala rumah tangga. Setelah data terkumpul kemudian dianalisis, menggunakan analisis deskriptif dengan tabel persentase.Hasil penelitian menunjukkan: 1). Faktor yang menyebabkan pengusaha industri genteng tidak berproduksi lagi, paling banyak disebabkan oleh keterbatasan modal berjumlah 6 pengusaha atau $42,85 \%$. Paling sedikit disebabkan oleh sulit memperoleh tenaga kerja, usia dan tidak ada generasi penerus serta kurang ketrampilan berinovasi, masing-masing berjumlah 1 pengusaha atau 7,15 \%. 2). Faktor pendorong industri genteng adalah merupakan mata pencaharian utama dengan jumlah paling banyak, yaitu 108 pengusaha atau $85,71 \%$. Faktor pendorong yang paling sedikit yaitu usaha dirintis sendiri berjumlah 5 pengusaha atau 3,97 \%. Faktor penarik yang paling banyak keuntungan cukup untuk memenuhi kebutuhan berjumlah 66 pengusaha atau 52,38 \% dan faktor penarik yang paling kecil yaitu membuka lapangan pekerjaan bagi lingkungan sekitar, berjumlah 4 pengusaha atau 3,97 \%. 3). Persebaran pengusaha industri genteng menunjukkan pola memanjang " linear " searah dengan jalan dan terdapat perbedaan aglomerasi industri genteng di tiga daerah sampel penelitian. 4). Pemasaran genteng ke luar kota, semua pengusaha yaitu 126 pengusaha atau 100 persen memasarkan ke Kota Yogyakarta. Pemasaran luar kota yang paling kecil ke Kota Semarang berjumlah 2 pengusaha atau 1,59 persen.
\end{abstract}

\section{Kata kunci : Industri genteng, tidak berproduksi}

\section{Pendahuluan}

Pembangunan industri kecil sangat bermanfaat bagi penduduk dan pemerintah. Manfaat bagi penduduk sebagai peluang pekerjaan dan menambah pendapatan. Bagi pemerintah dapat membantu mengatasi kemiskinan dan meningkatkan kesejahteraan 
penduduk, sehingga keadaan ekonomi penduduk dapat meningkat. Keberhasilan pembangunan ekonomi suatu negara dapat dilihat dari majunya sektor industri di desa, yang dapat meningkatkan taraf hidup masyarakat disekitarnya.

Industri pedesaan adalah suatu bentuk transisi antara industri yang bersifat tradisional dengan industri modern. Industri pedesaan dapat berfungsi sebagai alat pertumbuhan ekonomi. Industri pedesaan melalui mekanisme pasar dapat mengakumulasi dan mengalihkan modal dari sektor pertanian ke sektor industri. Industrialisasi pedesaan dapat pula meningkatkan penyerapan tenaga kerja yang senantiasa bertambah di pedesaan. Industrialisasi pedesaan juga berfungsi meningkatkan kesejahteraan sosial ekonomi. Industrialisasi pedesaan bertujuan untuk menganekaragamkan ekonomi pedesaan, melalui penciptaan lapangan kerja baru, peningkatan pendapatan dan peningkatan produktivitas ekonomi masyarakat pedesaan ( Marzuki Usman, 1990 : ii ).

Industri genteng di Desa Sidoluhur merupakan salah satu industri yang telah dikembangkan dan menjadi tulang punggung perekonomian di Desa Sidoluhur Kecamatan Godean Kabupaten Sleman. Agar industri genteng dapat dipertahankan maka, sektor industri ini harus dapat berkembang secara bertahap. Adanya industri genteng di Desa Sidoluhur juga tidak terlepas dari beberapa faktor yang mendorong (faktor dari dalam indutri) dan faktor yang menarik (faktor dari luar industri). Proses industri genteng membutuhkan tenaga kerja yang banyak, sehingga kegiatan ini dapat menyerap tenaga kerja dan meningkatkan kesejahteraan penduduk. Perkembangan industri genteng tidak seperti apa yang diharapkan, mengalami berbagai hambatan yang berhubungan dengan proses produksi. Adanya keterbatasan modal membuat industri ini kurang berkembang. Hambatan lainnya seperti kualitas bahan baku, yang sangat berhubungan dengan kualitas genteng. Keadaan cuaca dan berkurangnya bahan - bahan untuk pembuatan genteng akan memperlambat proses produksi. Selain faktor-- faktor tersebut industri ini juga mengalami hambatan dalam hal pemasaran dan persaingan antara pengusaha. Harga genteng juga bervariasi antara pengusaha satu dengan pengusaha yang lain, sehingga terjadi persaingan harga. Industri genteng di Desa Sidoluhur sulit berkembang, karena pengusaha industri genteng jumlahnya menurun. Sehingga terdapat beberapa industri genteng yang tidak berproduksi lagi. Maka keberadaan industri genteng tidak terlepas dari adanya faktor - faktor yang menyebabkan jumlah industri genteng semakin berkurang dan beberapa industri genteng tidak berproduksi lagi, serta faktor lokasi atau letak industri. Maka distribusi atau sebaran pengusaha industri genteng penting untuk diketahui. Ternyata di Desa Sidoluhur tidak terdapat peta sebaran pengusaha industri genteng dan peta pemasaran industri genteng.Tujuan dalam penelitian ini adalah untuk mengetahui: faktor - faktor yang menyebabkan pengusaha industri genteng tidak berproduksi lagi, faktor - faktor yang mendorong dan menarik pada usaha industri genteng, peta persebaran pengusaha industri genteng, dan pemasaran dan peta pemasaran genteng

\section{Metode Penelitian}

Penelitian ini merupakan penelitian deskrptif kuantitatif. Tahap-tahap yang dilalkukan dalam penelitian ini adalah: 
Penelitian ini dilaksanakan melalui tiga tahapan, yaitu tahap persiapan, tahap kerja lapangan dan tahap kerja akhir/penulisan laporan, adalah sebagai berikut :

a. Tahap Persiapan

Pada tahap ini langkah pertama adalah menentukan daerah penelitian, diikuti dengan kegiatan studi pustaka dan mengadakan observasi. Kemudian menyusun proposal penelitian, diteruskan dengan usulan penelitian. Setelah proposal penelitian disetujui dilanjutkan dengan seminar proposal penelitian. Sehingga didapatkan masukan untuk membantu jalannya penelitian. Kemudian pembenahan seperlunya sambil menyiapkan perlengkapan penelitian. Aktivitas akhir tahap persiapan ini adalah merencanakan kegiatan di lapangan.

b. Tahap Kerja Lapangan

Setelah aktivitas pada tahap persiapan selesai diteruskan dengan tahap kerja lapangan. Yaitu ketempat lokasi daerah penelitian, untuk mencari data primer yang diperoleh melalui wawancara dengan responden. Mengumpulkan informasi dan selalu memelihara hubungan harmonis dengan responden. Sehingga pada tahap ini merupakan suatu pengumpulan data yang efektif untuk memperoleh informasi yang relevan sebanyak - banyaknya dari responden. Serta selalu berpegang pada tujuan dan permasalahan penelitian. Hasil kerja lapangan adalah terkumpulnya data hasil kerja lapangan.

c. Tahap Kerja Akhir

Pada tahap kerja akhir ini dilakukan analisis data yang merupakan satu bagian tak terpisahkan dari tahap - tahap sebelumnya. Selanjutnya membuat laporan hasil penelitian. Analisis data dilakukan dalam suatu proses, dikerjakan sesudah semua data yang diperlukan terkumpul. Kegiatan akhir pada tahap ini adalah menulis laporan dalam bentuk laporan penelitian.

Variabel penelitian pada penelitian ini adalah sebagai berikut:

a. Faktor penyebab industri genteng tidak berproduksi lagi adalah : merupakan faktor yang menyebabkan kegiatan pengusaha industri genteng tidak berproduksi lagi. Faktor - faktor tersebut adalah, sulit memperoleh tenaga kerja dan bahan baku, persaingan antar pengusaha, usia dan tidak ada generasi penerus, keterbatasan modal dan kurang ketrampilan dalam berinovasi.

b. Faktor pendorong adalah : faktor dari dalam rumah tangga, yang menyebabkan bekerja pada usaha industri genteng. Faktor tersebut adalah, industri genteng merupakan mata pencaharian utama, usaha turun temurun dan usaha dirintis sendiri.

c. Faktor penarik adalah : merupakan faktor dari usaha industri genteng, yang menyebabkan rumah tangga tersebut tertarik dan bekerja pada usaha industri genteng. Faktor tersebut adalah, keuntungan cukup untuk memenuhi kebutuhan, membuka lapangan pekerjaan bagi lingkungan sekitar, banyak pesanan, usaha dikerjakan bebas tidak terikat jam kerja.

d. Pemasaran genteng adalah : kegiatan pendistribusian genteng di dalam dan ke luar kota, karena ada penawaran dan permintaan dari penjual kepada pembeli, setelah terdapat kesepakatan harga. 
Terdapat dua jenis populasi dalam penelitian ini. Pertama adalah populasi mantan pengusaha industri genteng yang berjumlah 14 kepala rumah tangga. Karena jumlahnya sedikit maka semua digunakan sebagai responden. Persebaran kepala rumah tangga mantan pengusaha industri genteng di Desa Sidoluhur adalah sebagai berikut : Dusun Berjo Kulon sebanyak 4 pengusaha atau 28,57 persen, Dusun Berjo Kidul sebanyak 8 pengusaha atau 57,14 persen dan Dusun Serangan sebanyak 2 pengusaha atau 14,29 persen. Populasi ini digunakan untuk menjelaskan tujuan penelitian yang pertama. Kedua adalah populasi kepala rumah tangga pengusaha industri genteng, berjumlah 388 pengusaha tersebar di 8 dusun. Dengan area sampling diambil 3 dusun, dusun pertama adalah dusun yang terletak paling dekat dengan jalan raya yaitu Dusun Berjo Kulon. Dusun kedua adalah dusun yang letaknya agak jauh dari jalan raya yaitu Dusun Berjo Kidul. Dusun ketiga adalah dusun yang letaknya jauh dari jalan raya yaitu Dusun Serangan. Ketiga dusun sampel juga merupakan dusun yang jumlah pengusahanya paling banyak dibandingkan dengan dusun laninnya. Dengan metode Solvin, diperoleh jumlah sampel sebagai berikut: Dusun Berjo Kulon 48 kepala rumah tangga, Dusun Berjo Kidul 33 kepala rumah tangga, dan Dusun Serangan 45 kepala rumah tangga.

Analisis data dalam penelitian ini menggunakan analisis deskriptif, menggunakan tabel persentase. Sebelum data dianalisis diadakan editing dan koding, agar data mudah dianalisis. Selanjutnya memindahkan data ke dalam tabel kemudian dianalisis dengan membaca dan menafsirkan tabel - tabel hasil penelitian berdasarkan persentase jumlahnya.

\section{Hasil dan Pembahasan}

1. Faktor Faktor yang Menyebabkan Pengusaha Industri Genteng Tidak Berproduksi Lagi

Sebagian besar penduduk di Desa Sidoluhur mengusahakan industri genteng, karena industri ini sudah merupakan mata pencaharian utama bagi penduduk. Tetapi sekarang jumlahnya semakin berkurang. Hal ini disebabkan sulit memperoleh tenaga kerja dan bahan baku, persaingan antar pengusaha, tidak ada generasi penerus, keterbatasan modal, kurang ketrampilan berinovasi. Faktor- faktor yang menyebabkan pengusaha industri genteng tidak berproduksi lagi adalah sebagai berikut:

Tabel 1. Faktor Faktor yang Menyebabkan Pengusaha Industri Genteng Tidak Berproduksi Lagi

\begin{tabular}{|c|l|c|c|}
\hline No & \multicolumn{1}{|c|}{ Faktor Penyebab } & $\begin{array}{c}\text { Jumlah } \\
\text { (Pengusaha ) }\end{array}$ & Persentase \\
\hline 1 & Sulit memperoleh tenaga kerja & 1 & 7,15 \\
\hline 2 & Sulit memperoleh bahan baku & 3 & 21,43 \\
\hline 3 & Persaingan antar pengusaha & 2 & 14,27 \\
\hline 4 & Usia dan tidak ada generasi penerus & 1 & 7,15 \\
\hline 5 & Keterbatasan modal & 6 & 42,85 \\
\hline 6 & Kurang ketrampilan berinovasi & 1 & 7,15 \\
\hline & & 14 & 100,00 \\
\hline
\end{tabular}

Sumber : Data Primer, 2013 
Faktor yang menyebabkan pengusaha industri genteng tidak berproduksi di Desa Sidoluhur paling banyak disebabkan oleh keterbatasan modal sebesar 6 pengusaha ( 42,85 persen ). Modal merupakan faktor produksi yang penting dalam suatu usaha sehingga usaha yang dijalankan dapat terus berproduksi. Karena modal terbatas maka menyebabkan industri genteng tidak dapat berproduksi lagi. Kemudian sulit memperoleh bahan baku sebesar 3 pengusaha ( 21,43 persen ), sulit memperoleh bahan baku, disebabkan terbatasnya alat angkut truk dan bahan baku di Desa Sidoluhur yaitu di Bukit Berjo sudah tidak dapat mencukupi lagi. Hal ini berdampak menghambat para pengusaha untuk menyediakan bahan baku. Sulit memperoleh tenaga kerja sebesar 1 pengusaha ( 7,15 persen ), hal ini mengakibatkan para pengusaha berfungsi ganda, selain sebagai pengusaha mereka juga sebagai tenaga kerja, sehingga dapat menghambat dalam proses produksi. Faktor usia dan tidak ada generasi penerus serta kurang ketrampilan berinovasi, masing - masing 1 pengusaha ( 7,15 persen ). Faktor usia dikarenakan usia sudah lanjut atau tua. Sehingga tidak ada generasi penerus, karena generasi muda saat ini tidak tertarik dengan usaha industri genteng. Kurang ketrampilan berinovasi adalah pengusaha belum melakukan inovasi produk. Produk genteng yang dihasilkan kurang bervariasi, hanya satu jenis produk yaitu genteng jenis paris saja atau genteng biasa, sedangkan selera konsumen sudah berubah. Sehingga tidak dapat bersaing dan berhenti tidak berproduksi lagi.

2. Faktor Pendorong dan Penarik pada Usaha Industri Genteng

Meskipun jumlah pengusaha industri genteng berkurang, ternyata masih terdapat beberapa pengusaha industri genteng yang tetap berusaha untuk mempertahankan agar usahanya tetap dapat berjalan. Hal ini karena terdapat faktor faktor yang mendorong dan menarik pada usaha industri genteng, adalah sebagai berikut :

Tabel 2. Faktor Pendorong dan Penarik pada Usaha Industri Genteng

\begin{tabular}{|c|c|c|c|c|c|c|}
\hline No & $\begin{array}{l}\text { Faktor } \\
\text { Pendorong }\end{array}$ & $\begin{array}{c}\text { Jumlah } \\
\text { Pengusaha }\end{array}$ & $\%$ & Faktor Penarik & $\begin{array}{c}\text { Jumlah } \\
\text { Pengusaha }\end{array}$ & $\%$ \\
\hline 1 & $\begin{array}{l}\text { Mata } \\
\text { pencaharian } \\
\text { utama }\end{array}$ & 108 & 85,71 & Pemasaran lancar & 42 & 33,33 \\
\hline 2 & $\begin{array}{l}\text { Usaha turun } \\
\text { Temurun }\end{array}$ & 13 & 10,32 & $\begin{array}{l}\text { Keuntungan cukup untuk } \\
\text { memenuhi kebutuhan }\end{array}$ & 66 & 52,38 \\
\hline 3 & $\begin{array}{l}\text { Usaha dirintis } \\
\text { Sendiri }\end{array}$ & 5 & 3,97 & $\begin{array}{l}\text { Membuka lapangan } \\
\text { pekerjaan bagi lingkungan } \\
\text { sekitar }\end{array}$ & 4 & 3,17 \\
\hline 4 & - & - & - & Banyak pesanan & 9 & 7,17 \\
\hline 5 & - & - & - & $\begin{array}{l}\text { Usaha dikerjakan bebas } \\
\text { tidak terikat jam kerja }\end{array}$ & 5 & 3,97 \\
\hline & Jumlah & 126 & 100,00 & Jumlah & 126 & 100,00 \\
\hline
\end{tabular}

Sumber : Data Primer

Faktor pendorong dalam penelitian ini yaitu, usaha industri genteng merupakan mata pencaharian utama sebesar 108 pengusaha ( 85,71 persen ), karena penduduk di 
Desa Sidoluhur banyak yang mendapatkan penghasilan dari usaha industri genteng. Usaha industri genteng merupakan usaha turun temurun sebesar 13 pengusaha ( 10,32 persen ), hal ini menunjukkan bahwa pengusaha berusaha melestarikan industri genteng. Karena industri ini merupakan warisan dari orang tua, sehingga sampai sekarang usaha industri genteng masih dapat berjalan, meskipun jumlahnya cenderung berkurang. Disamping itu usaha industri genteng merupakan usaha yang dirintis sendiri sebesar 5 pengusaha ( 3,97 persen ). Pengusaha yang merintis usaha sendiri ini awalnya sebelum manjadi pengusaha mereka bekerja sebagai buruh pada industri genteng. Kemudian mereka berusaha untuk mendirikan dan menjalankan usaha sendiri. Maka mereka berusaha untuk selalu menjaga agar usahanya dapat berjalan terus.

Faktor penarik dalam penelitian ini yaitu pemasaran yang lancar sebesar 42 pengusaha ( 33,33 persen), menarik pengusaha menekuni usahanya sampai sekarang masih memproduksi genteng. Keuntungan dapat memenuhi kebutuhan sebesar 66 pengusaha ( 52,38 persen ), terutama untuk memenuhi kebutuhan primer rumah tangganya. Usaha industri genteng dapat membuka lapangan pekerjaan sebesar 4 pengusaha ( 3,17 persen ), karena proses produksi industri genteng membutuhkan tenaga kerja yang banyak, maka dapat membuka lapangan pekerjaan bagi lingkungan sekitar. Banyaknya pesanan juga merupakan faktor penarik sebesar 9 pengusaha ( 7,14 persen ), karena selain dari konsumen yang membeli secara langsung, ada beberapa juragan ( industri skala besar ) memesan genteng pada industri skala rumah tangga untuk memenuhi permintaan konsumen. Faktor penarik lainnya adalah waktu dapat dikerjakan tidak terikat jam kerja sebesar 5 pengusaha ( 3,97 persen ). Jam kerja produksi genteng dapat dilakukan malam hari, kecuali proses penjemuran genteng, karena penjemuran genteng masih menggunakan panas dari sinar mata hari. Maka penjemuran genteng dikerjakan pada siang hari.

3. Persebaran Pengusaha Industri Genteng

Persebaran pengusaha industri genteng ini merujuk pada lokasi industri, berjumlah 126 pengusaha. Adalah sebagai berikut :

Tabel 3. Persebaran Industri Genteng

\begin{tabular}{|c|l|c|c|}
\hline No & Dusun & Jumlah industri & Persentase \\
\hline 1 & Berjo Kulon ( dekat ) & 48 & 38,10 \\
\hline 2 & Berjo Kidul (agak jauh ) & 33 & 26,19 \\
\hline 3 & Serangan ( jauh ) & 45 & 35,71 \\
\hline & Jumlah : & 126 & 100,00 \\
\hline
\end{tabular}

Sumber : Data Primer 2013

Penelitian ini mengambil tiga dusun sebagai daerah penelitian, dengan aksessibilitas yang berbeda-beda. Pertama Dusun Berjo Kulon dengan jumlah 48 atau 38,10 persen, lokasi dusun ini dekat dengan jalan raya, merupakan sentra industri genteng Desa Sidoluhur. Kedua dusun Berjo Kidul dengan jumlah 33 industri atau 26,19 persen, lokasi dusun ini berada agak jauh dari jalan raya. Ketiga Dusun Serangan 
dengan jumlah 45 industri atau 35,71 persen, lokasi dusun ini berada jauh dari jalan raya. Peta persebaran pengusaaha industri genteng adalah sebagai berikut :

Dari peta tersebut dapat disimpulkan bahwa sebaran industri genteng di Desa Sidoluhur menggambarkan pola memanjang atau "linear" searah dengan jalan di semua dusun penelitian. Berarti adanya jalur transportasi berhubungan dengan mudah tidaknya lokasi industri genteng tersebut dijangkau, guna mendistribusikan hasil industri genteng. Karena lokasi dusun sampel penelitian berbeda aksessibilitasnya, maka terdapat perbedaan aglomerasi atau pengelompokan skala industri genteng, yaitu sebagai berikut : 1). Di Dusun Berjo Kulon dekat jalan raya, terdapat aglomerasi pengusaha industri genteng skala besar. 2). Di Dusun Berjo Kidul agak jauh dari jalan raya, terdapat aglomerasi pengusaha industri genteng skala menengah dan skala rumah tangga. 3). Di Dusun Serangan jauh dari jalan raya, terdapat aglomerasi pengusaha industri skala rumah tangga.

4. Daerah Pemasaran Genteng

Pemasaran pada industri genteng pada pembahasan ini adalah pemasaran ke daerah tujuan, yaitu pemasaran ke luar kota adalah sebagai berikut:

Tabel 4. Daerah Tujuan Pemasaran Genteng ke Luar Kota

\begin{tabular}{|ll|c|c|}
\hline \multicolumn{1}{|c|}{ Daerah Pemasaran } & Jumlah Pengusaha & Persentase \\
\hline 1. & Yogyakarta & 126 & 100,00 \\
\hline 2. & Klaten & 33 & 26,19 \\
\hline 3. & Solo & 49 & 38,89 \\
\hline 4. Magelang & 66 & 52,38 \\
\hline 5. & Temanggung & 18 & 14,29 \\
\hline 6. Salatigo & 42 & 3,17 \\
\hline 7. & Semarang & 2 & 1,59 \\
\hline 8. & Purworejo & 20 & 15,87 \\
\hline
\end{tabular}

Sumber : Data Primer, 2013

Pemasaran ke luar kota yang paling kecil adalah ke Kota Semarang sebesar 2 pengusaha atau 1,59 persen. Pemasaran yang paling banyak ke kota Yogyakarta, karena semua pengusaha mengirim ke kota tersebut, sebesar 126 pengusaha atau 100,00 persen. Kemudian diikuti kota Magelang dan Solo, masing - masing sebesar 66 pengusaha atau 52,38 persen dan sebesar 49 pengusaha atau 38,89 persen. Hal ini disebabkan faktor jarak antara daerah tersebut. Gejala ini menunjukkan adanya interaksi yang besar diantara dua daerah yang jaraknya semakin dekat yaitu Kota Yogyakarta dengan Desa Sidoluhur Kecamatan Godean Kabupaten Sleman. Dan interaksi yang semakin kecil antara dua daerah, karena jaraknya semakin jauh. Peta pemasaran genteng dari Desa Sidoluhur adalah sebagai berikut :

\section{Simpulan}

1. Faktor penyebab pengusaha industri genteng tidak berproduksi lagi, karena adanya kesulitan memperoleh bahan baku dan tenaga kerja, keterbatasan alat angkut, usia dan tidak ada generasi penerus.

2. Faktor pendorong pada industri genteng yaitu, industri genteng merupakan mata pencaharian utama, usaha turun temurun dan usaha dirintis sendiri. 
3. Faktor penarik pada industri genteng adalah, adanya pemasaran yang lancar, keuntungan cukup untuk memenuhi kebutuhan, membuka lapangan pekerjaan bagi lingkungan sekitar, banyak pesanan, usaha dikerjakan secara bebas tidak terikat waktu.

4. Pemasaran genteng ke luar kota paling banyak ke Kota yogyakarta dan yang terkecil ke Kota Semarang.

5. Peta sebaran pengusaha industri genteng menggambarkan pola persebaran industri genteng adalah memanjang atau linear searah dengan jalan.

6. Terdapat perbedaan aglomerasi atau pengelompokan industri genteng, karena adanya perbedaan aksessibilitas.

\section{Saran}

1. Industri genteng di Desa Sidoluhur, dapat memberikan kesempatan kerja bagi penduduk, maka keberadaan industri ini harus tetap dijaga. Pemerintah diharapkan dapat membantu mengatasi segala kesulitan yang ada sehingga industri ini tetap berproduksi terus.

2. Dengan adanya faktor pendorong dan penarik pada industri genteng, maka industri genteng tersebut perlu dikembangkan dan dijaga kelestariannya.

3. Pemerintah diharapkan dapat membentu pengembangan jaringan pemasaran, sehingga dapat membantu memperlancar kegiatan ekonomi penduduk.

\section{Daftar Pustaka}

Ida Bagus Mantra. 2004. Demografi Umum. Yogyakarta : Pustaka Pelajar Marzuki Usman. 1990. Industri Pedesaan. Bogor : Pusat Studi Pembangunan Sugiyono. 2012. Metode Penelitian Kombinasi ( Mixed Methods). Bandung : Alfabeta. 